Radiocarbon, Vol 57, Nr 1, 2015, p 47-64

DOI: $10.2458 / a z u \_r c .57 .17925$

(C) 2015 by the Arizona Board of Regents on behalf of the University of Arizona

\title{
THE TEMPO OF BRONZE AGE BARROW USE: MODELING THE EBB AND FLOW IN MONUMENTAL FUNERARY LANDSCAPES
}

\author{
Quentin P J Bourgeois \\ Faculty of Archaeology, Leiden University, P.O. Box 9514, 2300 RA Leiden, the Netherlands; also Prehistoric Archaeology, \\ Department of Culture and Society, Aarhus University, Denmark. Corresponding author. \\ Email: q.p.j.bourgeois@arch.leidenuniv.nl. \\ David R Fontijn \\ Faculty of Archaeology, Leiden University, P.O. Box 9514, 2300 RA Leiden, the Netherlands.
}

\begin{abstract}
The thousands of Bronze Age burial mounds of northwestern Europe often have complex histories, with multiple construction phases and secondary burials added to these mounds. It can be difficult to understand the dynamic nature of these events and the ebb and flow of activities in these monumental funerary landscapes. This article presents chronological models of five Bronze Age barrows from two sites. A total of 41 radiocarbon-dated cremation burials were fitted into several chronological sequences. The results from the chronological models at both sites suggest that the creation of a burial mound was just one event within a much longer funerary history. For both sites, there are indications that the deceased were buried in flat graves decades and sometimes more than a century prior to any monument construction. Once in place, the barrows were then used as a repository for the dead for decades afterwards. At the same time, a comparison of the models suggests that funerary events at both sites were punctuated. At one site, several barrows were in use simultaneously, at the other, barrows seem to be each other's successor. The models provide evidence for both protracted histories as well as punctuated events.
\end{abstract}

\section{INTRODUCTION}

Bronze Age barrows rank among the most noticeable remains of later prehistory, and tens of thousands can still be found throughout northwestern Europe. The continuous accumulation of these mounds created vast palimpsest funerary landscapes with complex arrangements of monuments (Woodward and Woodward 1996; Garwood 2007; Bourgeois 2013). Furthermore, barrow use in the Bronze Age was dynamic in nature. Burial mounds were usually built in several construction phases, and many burials were added to these mounds after their erection. There is a wealth of evidence to be found in excavation reports on patterns of abandonment and reuse of single monuments (Glasbergen 1954; Mizoguchi 1993; Holst 2013), yet the tempo of these events is still poorly understood.

The modeling of the ebb and flow of activities in barrow landscapes is fundamental for understanding them in social and demographic terms. Were small groups of people occasionally using these barrows over a long period of time, or should we rather think of larger groups of people who buried a large number of dead here in a very short period? Getting an idea on the time that passed between use-phases of a barrow may also inform us whether or not prehistoric mourners could have had accurate knowledge on the identity of prior burials (Lohof 1994:102; Gosden and Lock 1998; Bradley 2003:221). However, providing the answer to these questions is no easy matter as conventional ${ }^{14} \mathrm{C}$-based chronologies at the moment do not provide the necessary resolution (Garwood 2007; Whittle and Bayliss 2007). At best, the chronological resolution that usually can be achieved is in centuries rather than decades. The lack of information on the more exact chronological position of each individual grave with respect to the others forces us to create broad time slices in which all events are treated as contemporaneous (Bailey 2007; Whittle 2011).

Fortunately, as has been successfully demonstrated in the last few years, the application of Bayesian statistics allows for the construction of a more detailed chronology (Whittle and Bayliss 2007; Bayliss 2009; Bronk Ramsey 2009; Whittle 2011). With this method, information on the sequence of events from other sources - such as stratigraphy - is taken into account to refine the chronological model. For a detailed discussion on the use of Bayesian statistics in radiocarbon dating, see Bayliss (2009), Bronk Ramsey (2009), and Bayliss et al. (2011). This method is particularly useful 
in the case of barrows as these usually were built and used in several phases and events. Taking the stratigraphic position of particular burials or events into account may enable us to construct a finer chronology.

By applying such Bayesian modeling to ${ }^{14} \mathrm{C}$-dated Bronze Age barrow data, we think we can come to a better and more detailed understanding of the different tempi of funerary events at barrow sites. This article will first present the results of two case studies and will then discuss the implications these models may have for the study of Bronze Age funerary landscapes.

\section{CASE STUDIES}

In order to investigate the tempo of barrow construction and burial, we selected two sites in the Netherlands ( $\sim 14 \mathrm{~km}$ apart, Figure 1) that are suitable for such investigations: Garderen-Bergsham excavated by Van Giffen in 1935 (Van Giffen 1937) and Apeldoorn-Wieselse Weg excavated by our research team in 2008 and 2009 (Louwen et al. 2014). At both sites, several barrows were built during the Middle Bronze Age, and although the Garderen-Bergsham site was excavated by Van Giffen more than $75 \mathrm{yr}$ ago, the quality of the excavation and its documentation is of a relative high quality, allowing us to reconstruct several construction events. Also, numerous secondary graves were discovered, indicating that people in the Bronze Age returned to these monuments to bury their dead. For both sites, all primary and secondary burials where bone remains were available were ${ }^{14} \mathrm{C}$ dated (all cremation graves). We (re-)evaluated the stratigraphic position of all burials.

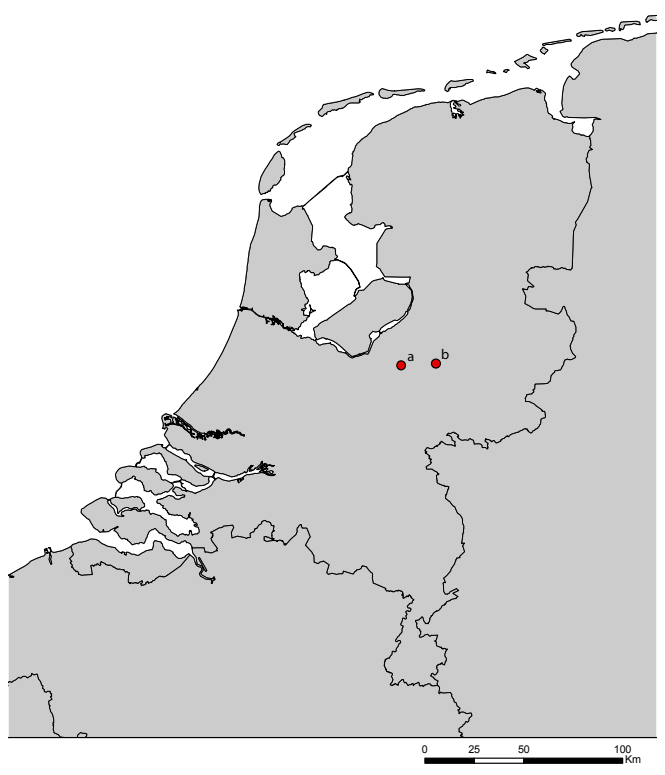

Figure 1 The location of the (a) Garderen-Bergsham and (b) Wieselse Weg burial mounds within the Netherlands.

In total, we obtained $41{ }^{14} \mathrm{C}$ dates from samples of cremated human bone from the graves at both sites. All dated samples were selected by the physical anthropologist who studied the bones (Smits $2011 \mathrm{a}, \mathrm{b})$ and all were very well burnt $\left(>600^{\circ} \mathrm{C}\right.$; white color all through the sample). If possible, parts of the long bones were dated. All ${ }^{14} \mathrm{C}$ measurements were performed by the Groningen AMS facility and the surface of the bones was pretreated in order to minimize any secondary carbonate contamination (following the protocol set out by Van Strydonck et al. 2009:566). 


\section{Garderen-Bergsham Barrows}

The site of Garderen-Bergsham consists of six barrows that lie in close proximity to one another (Figure 2). They are located on what is locally the highest point in the hilly landscape of the icepushed ridges of the Veluwe in the central Netherlands. In 1935, Van Giffen excavated parts of four of these barrows in minute detail (Van Giffen 1937). He excavated mounds 3 and 3' almost entirely, a single quadrant of mound 2, and dug two narrow trenches through mound 5 (Van Giffen 1937:Figure 9). In total, no less than 44 burials were documented from these four mounds (both inhumation and cremation graves). As one of these burials (no. 25) is associated with a bronze Wohlde sword, it has attracted quite a lot of attention over the years, and the site has been reinterpreted several times since (Glasbergen 1954:146; Lanting and van der Plicht 2003:194).

Figure 2 Simplified map of the three Garderen-Bergsham barrows mentioned in the text as excavated by Van Giffen [redrawn with permission of the Groningen Insitute of Archaeology (GIA) after Van Giffen 1937:Figure 9]. Depicted are the excavation trenches in mound 3,3 , and 5 . The drawing is a composition of multiple excavation levels recorded at differing heights within the mounds and for the sake of clarity, graves found at different levels are now combined in one overview. Additional excavation levels are depicted on Van Giffen (1937:Figure 9). Note that not all burials are indicated in this drawing. The field drawings kept at the GIA contain much greater detail and have been used as a basis for this article.

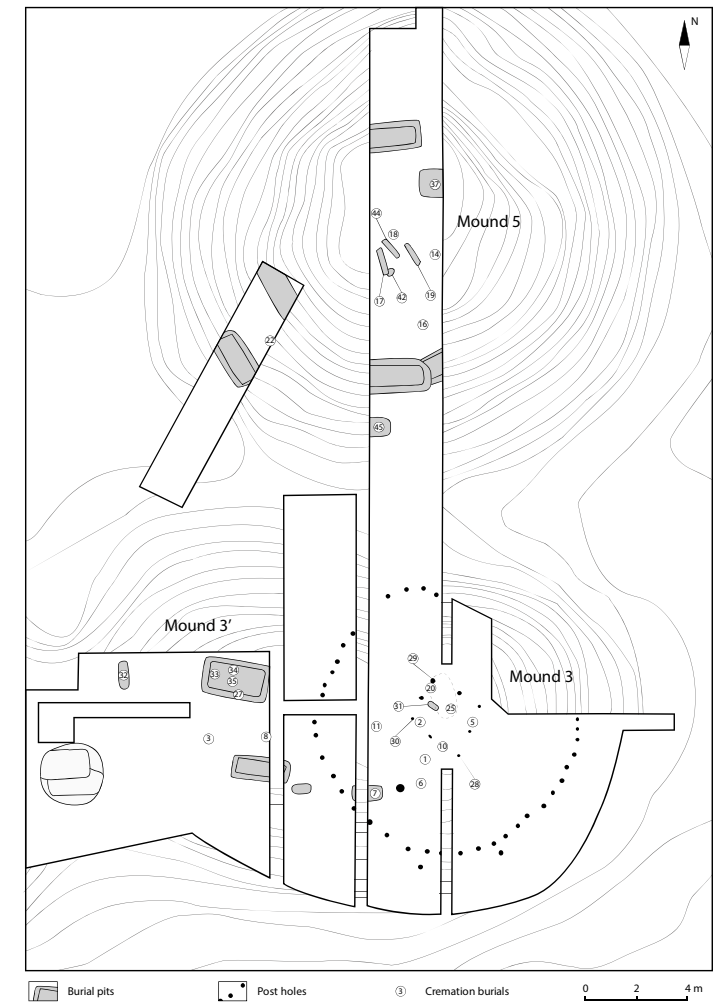

Recently, the site has been re-evaluated and many new ${ }^{14} \mathrm{C}$ dates could be added to the three available so far (Lanting and van der Plicht 2003:194). Out of the 44 burials in these barrows, 30 were cremation burials and 29 have recently been ${ }^{14} \mathrm{C}$ dated. In most of the inhumation burials, bones were not preserved due to the acidity of the soil. As we have a good grasp on the stratigraphy of the site and since most burials could be attributed to specific phases, this site seemed promising for our study. In this reconstruction we will only address the evidence from three of the four excavated barrows (Mound 3, Mound 3', and Mound 5), as it was not possible to retrieve any of the finds from the fourth barrow (Mound 2); 23 out of the 29 cremation burial could be fitted into the chronological models. We excluded six burials from the models, mainly due to concerns with their provenance. ${ }^{1}$

1. Grave nos. 2 and 29 contained too few remains to yield a reliable dating. No. 5 could not be retrieved. Graves that are dated but not included in the models are 18/38 (it is uncertain which grave is meant by the label "18/38"; GrA-50035: $3315 \pm$ $40 \mathrm{BP}$ ) and 1 and 12 (confusing information on the find list/labels; respectively, GrA-50039: $3315 \pm 40 \mathrm{BP}$ and GrA-50047: $3055 \pm 40 \mathrm{BP}$ ). There are no such problems with grave 32 , but this grave could not be directly linked to a profile section and is omitted for that reason (GrA-50068: $3345 \pm 40 \mathrm{BP}$ ). 
The sequence of events as could be established by us for each barrow is summarized below.

\section{Barrow 3}

Prior to the construction of mound 3, there were already several funerary activities taking place (Phase 3-I). First, the foot of the barrow covered a shallow pit with cremated remains (grave 7A; Van Giffen 1937, Figure 9, square P 16; profile b-b' 16 (lowest grave). ${ }^{2}$ To the northeast, another burial pit was discovered (grave 31), containing cremated remains of two individuals buried deep in the ground at a location that would become the center of the mound (Van Giffen 1937:10; Smits 2011a). Surrounding this burial pit were the traces of eight heavy posts, forming a "mortuary house" (Lanting and van der Plicht 2003:194). In the upper fill of three of the four corner-post fragments, cremated human remains have been found (nos. 28-30; respectively $16 \mathrm{~g}, 1 \mathrm{~g}$, and $4 \mathrm{~g}$ ). Both no. 28 and 30 have been ${ }^{14} \mathrm{C}$ dated.

Following this pre-barrow phase, a small and low barrow was built (Lanting and van der Plicht 2003:194), sealing off the burials underneath it, and probably encapsulating the (remains of) the mortuary house. After some period of time, two cremation burials were deposited in the center of the barrow (Phase 3-II; grave 20 and 25). These were situated in a "thick" layer of cremated bone and charcoal (Van Giffen 1937:10), covering the center of the mound around where the prehistoric surface must have been and $\sim 65 \mathrm{~cm}$ higher than grave 31. A bronze Wohlde sword was placed on top of cremation burial 25 (Van Giffen 1937:Figure 9). Once these burials were placed in the center, the burials and the low barrow were covered in a new layer of turf. The newly created mound was then surrounded by a post-circle (cf. Lanting and van der Plicht 2003:194).

Van Giffen (1937) demonstrated that after completing the mound at least six additional cremation burials were dug into the body of the mound (Phase 3-III; burials 1, 2, 5, 6, 10 and $11 ;{ }^{14} \mathrm{C}$ dates of the latter three are used here). People also fused this mound with barrow 3 ' by adding a new layer of turf, but whether this happened before or after these graves were dug in could not be established.

\section{Barrow 3'}

To the west of mound 3 a new small mound was constructed, and as with the previous barrow, it covered the remains of several individuals. Here, the primary grave (cf. Van Giffen 1937:9) is a rectangular pit/small chamber with (charred) wood lining the walls. It contained three distinct piles of cremated remains (burials 33-35, Phase 3'-I).

Once the mound was in place, at least three more cremation burials were dug into the body of the mound: nos. 8, 21, and 27. The latter was dug through the remains of the central chamber. All three cremation burials have been dated (Phase 3'-II). At some point in time, this mound was fused with mound 3 (see above). A seventh cremation burial was also ${ }^{14} \mathrm{C}$ dated but could not be assigned reliably to either of these phases (burial 32).

\section{Barrow 5}

The barrow to the north of barrows 3 and 3' also started off with a pre-barrow phase with multiple cremation burials covered by the primary barrow. Here, at the center of the monument, three burial

2. Van Giffen (Figure 9; profile b-b' 16) shows two cremation graves in the profile, one clearly dug into the top of the mound and a lower one clearly dug into the original surface and covered by that mound. They are not numbered here, nor in the original field drawing, but the plan shows grave "7" here at P-O 16. The original find list describes two cremation graves: 7 and 7A. We only retrieved bones from grave 7A. The find list mentions that grave 7A is a "cremation grave but slightly deeper than 7" (translation ours). Height mentioned here is 51.20-51.15 +NAP. Based on Van Giffen's Figure 9 P-O 16, we identify the graves in profile b-b' 16 as 7 (the highest one) and 7A must be the lower one dug into the original surface and covered by the mound. The height mentioned for 7A, however, does not correspond with the height for profile b-b' (the lowest grave should be around 50.90-51+ NAP). 
pits with cremated remains could be identified at the lowest excavation level (Phase 5-I; burials 37, 42 and 44). The profile section shows how burial 37 was covered with a very low barrow $(60 \mathrm{~cm}$ high; Van Giffen 1937:Figure 9: a-a', 3-4). As burials 42 and 44 were only found at the deepest excavation level (50.24 and 50.65, respectively; cf. Van Giffen 1937:Figure 9 and excavation find list), the same must apply to these two graves.

The field drawings are somewhat unclear (cf. Van Giffen 1937:Figure 9), but to judge by the height at which they were found, at least two cremation burials were dug into the top of a low mound standing at this location (Phase 5-II; nos. 17 and 19). This may be the first mound mentioned above, or a version of it that was already slightly raised by that time. It is certain that from that moment on, the barrow was raised with turfs several times until it became the biggest barrow at the site $(\sim 2.15 \mathrm{~m} \mathrm{high})$. Van Giffen (1937:12) recognized at least five construction phases. However, as the different field drawings contradict one another on the number of covering layers, it proved impossible for us to attribute the remainder of the burials to specific phases. Therefore, they have all been lumped together in a single phase, although it should be noted that these may originate from separate layers (Phase 5-III; nos. 14,16 , and 45). Here also, inhumation burials were recognized throughout phase II and phase III, but since no datable material has been recovered from these, they have not been included in this model.

\section{Bergsham Models}

Each barrow sequence has been translated into individual chronological models with contiguous phases, calculated with OxCal v 4.2 (Bronk Ramsey 2009) and the IntCal13 calibration curve (Reimer et al. 2013). The results are summarized below (Figures 3, 4, and 5 for barrow 3, 3', and 5, respectively; Tables 1, 2, and 3). All three models have good overall agreement $\left(\mathrm{A}_{\text {overall }}=101.9 \%\right.$, $105.8 \%$, and $112.1 \%$, respectively). Along with the construction of the chronological model, the timespan of each phase and the interval in between has been calculated as well (Figure 6).

The models suggest that the first individuals interred at the Bergsham site were those underneath barrow 3 (Phase 3-I). The earliest pre-barrow burials were probably placed here in the 19th or 18th century cal $\mathrm{BC}$, and the latest, probably in the 17 th century cal $\mathrm{BC}$. This relatively long estimate for the duration of the phase is reflected in the posterior density estimates for the individual burials. Grave 7A can, according to the model, be dated between 1880-1660 cal BC (at $95.4 \%$ probability). Burial 31 on the other hand, is dated between $1745-1610 \mathrm{cal} \mathrm{BC}$ (at 95.4\%). There is not much overlap between graves 7A and 31. This suggests that it took some time before a barrow was built at this location. Burial 7A must therefore be regarded as a flat grave. Probably one, perhaps even two centuries afterwards, cremated remains were deposited in burial pit 31 .

It is important to note, however, that the chronological model does not directly date the construction of the monuments at the site. It only puts constraints on modeling the moment in time when these people were buried. Yet, if we assume that barrow construction quickly followed after the last primary burials were added to the site (i.e. burial 31), then the model suggests that the first barrow to be constructed was mound 3-I, probably in the late 18th or more likely the 17th century BC.

The encapsulating of the mortuary house with a small barrow marked the end of this pre-barrow phase. Intriguingly, this low barrow was the only burial monument at the site for a certain period of time (see below). This location was not used for burial for perhaps a couple of decades, although no more than $76 \mathrm{yr}$ (at $95.4 \%$ probability). After this period of time, the burial of two cremations, one with a sword, in this barrow (nos. 20 and 25; Phase 3-II) signals a considerable change in the pace of the events. Within a few decades, somewhere by the end of the 17th century BC or first half of the 16th century BC, barrow 3 was considerably increased in size and both mounds 3 ' and 5 were 

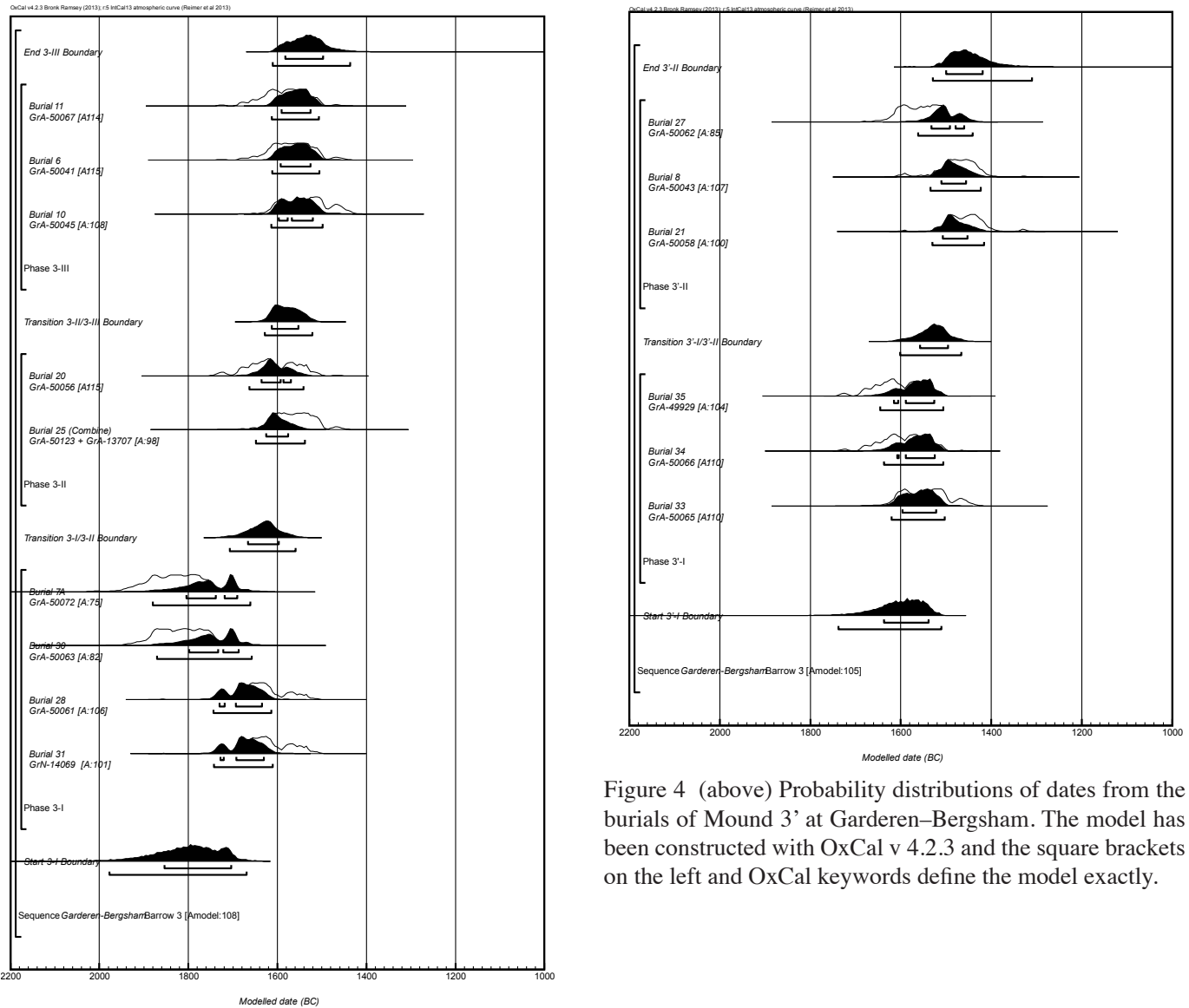

Figure 4 (above) Probability distributions of dates from the burials of Mound 3' at Garderen-Bergsham. The model has been constructed with $\mathrm{OxCal} \vee 4.2 .3$ and the square brackets on the left and OxCal keywords define the model exactly.

Figure 3 (above left) Probability distributions of dates from the burials of Mound 3 at Garderen-Bergsham. The model has been constructed with $\mathrm{OxCal}$ v 4.2.3 and the square brackets on the left and OxCal keywords define the model exactly. GrA-14069 (burial 31) and one dating of burial 25 (GrA-13707) were published by Lanting and van der Plicht (2003:194).

constructed (Phase 3'-I and Phase 5-I), each covering multiple burials (Figure 4 and 5). The similar spread of the individual ${ }^{14} \mathrm{C}$ dates strongly suggests that these three construction events occurred close in time to one another. This is reflected in the estimated relatively brief duration of each of these phases (Figure 6). It suggests that the people buried underneath the mounds of Phase 3-II, 3'-I, and 5-I all died within one or two generations of one another (particularly 3-II and 5-I).

For all three barrows, a phase of secondary burial followed (Phase 3-III; Phase 3'-II; and Phases 5-II and 5-III). The majority of secondary graves are estimated to have been added to these mounds over the span of a little more than a century, the 16th century BC and the first half of the 15th century BC (Figures 3-5). Here too, the estimated intervals and durations for all three barrows suggests most secondary burials were added to the mounds shortly after their construction and that these burial events were very near in time to one another. This is particularly the case for phases 3-III and 5-II where the intervals between mound construction phases and secondary burial are $<40 \mathrm{yr}$ (at $95.4 \%$ probability), possibly even $<15 \mathrm{yr}$ (at $68.2 \%$ ). In one case, secondary burial continued for a longer period of time, as is evidenced by burial 45 (Figure 5). ${ }^{3}$

3. Although the inhumation burials could not be included in this model, there is no reason to think that the ones uncovered may potentially conflict with it. Stratigraphy alone indicates cremation graves are the oldest burials in all three barrows. 


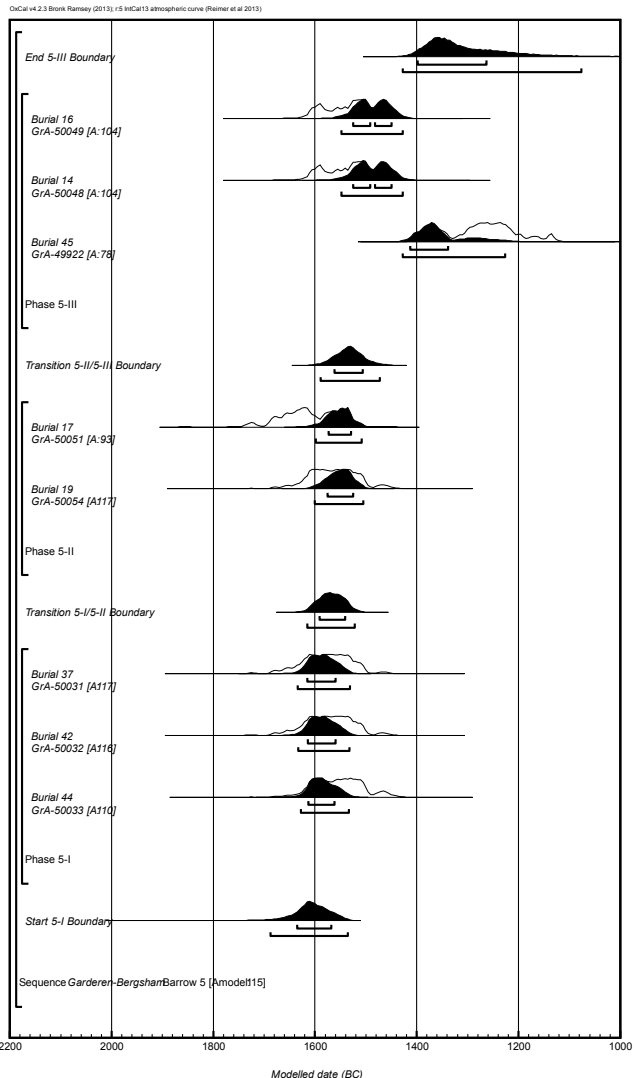

Figure 5 Probability distributions of dates from the burials of Mound 5 at Garderen-Bergsham. The model has been constructed with OxCal v 4.2.3 and the square brackets on the left and OxCal keywords define the model exactly.

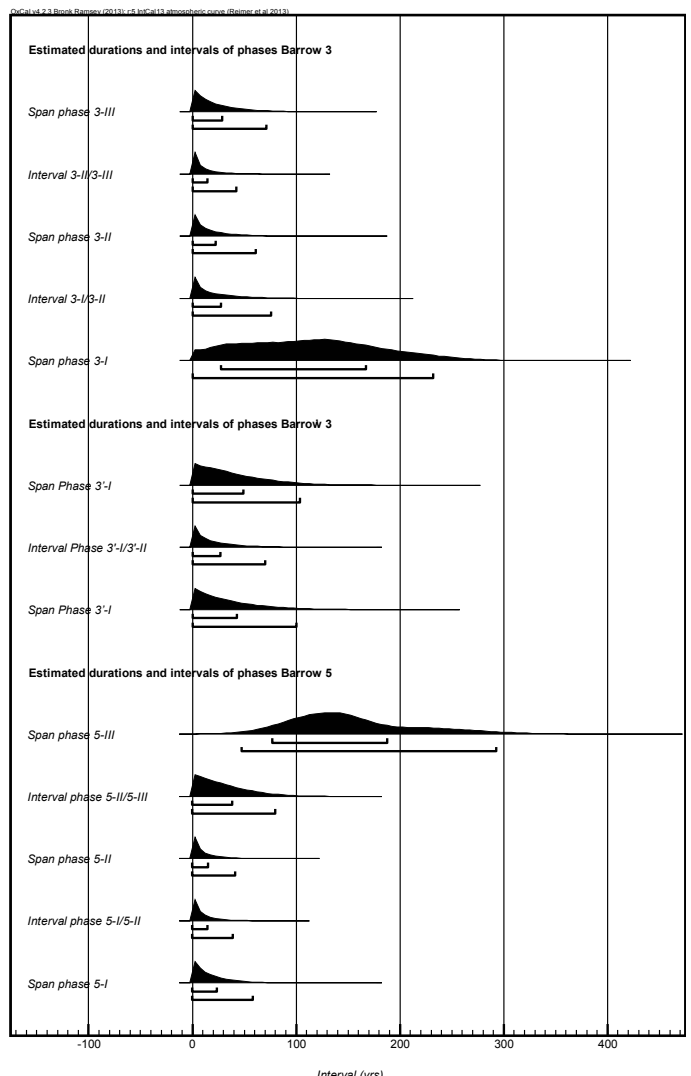

Figure 6 Probability distributions estimating the duration and interval between each phase at the Garderen-Bergsham site. These distributions are derived from the models in Figures 3,4 , and 5 .

Summarizing, the events at the Bergsham site started with a single flat grave in the 19th or 18th century $\mathrm{BC}$. In the 17 th century $\mathrm{BC}$, a mortuary house was constructed covering and containing the cremated remains of two individuals (grave 31). The wooden construction was eventually encapsulated in a relatively small and low barrow. Around $1600 \mathrm{cal} \mathrm{BC}$, this low mound was used as the repository for at least two more cremation burials. It was then increased in size with a new layer of sods and at least two new mounds were constructed in the vicinity - each covering multiple burials. In the century following their construction, dozens of secondary burials (both inhumation and cremation) were added to these three mounds. After about 100 to $150 \mathrm{yr}$, the practice abated and secondary burial became incidental.

\section{Apeldoorn-Wieselse Weg Barrows}

Our second case study concerns a group of three barrows some $14 \mathrm{~km}$ from the Bergsham site, located on the eastern slopes of the ice-pushed ridges in the central Netherlands. In 2008 and 2009, we excavated a quarter of each of these mounds, revealing a series of cremation burials in each of them (for an account on the stratigraphical position of the graves, see Louwen et al. 2014). Of particular interest to this article are both barrows 2 and 3 as these are very similar to the Bergsham mounds apart from the fact that at Wieselse Weg, no inhumation graves were found, just cremation graves (Figure 7). 


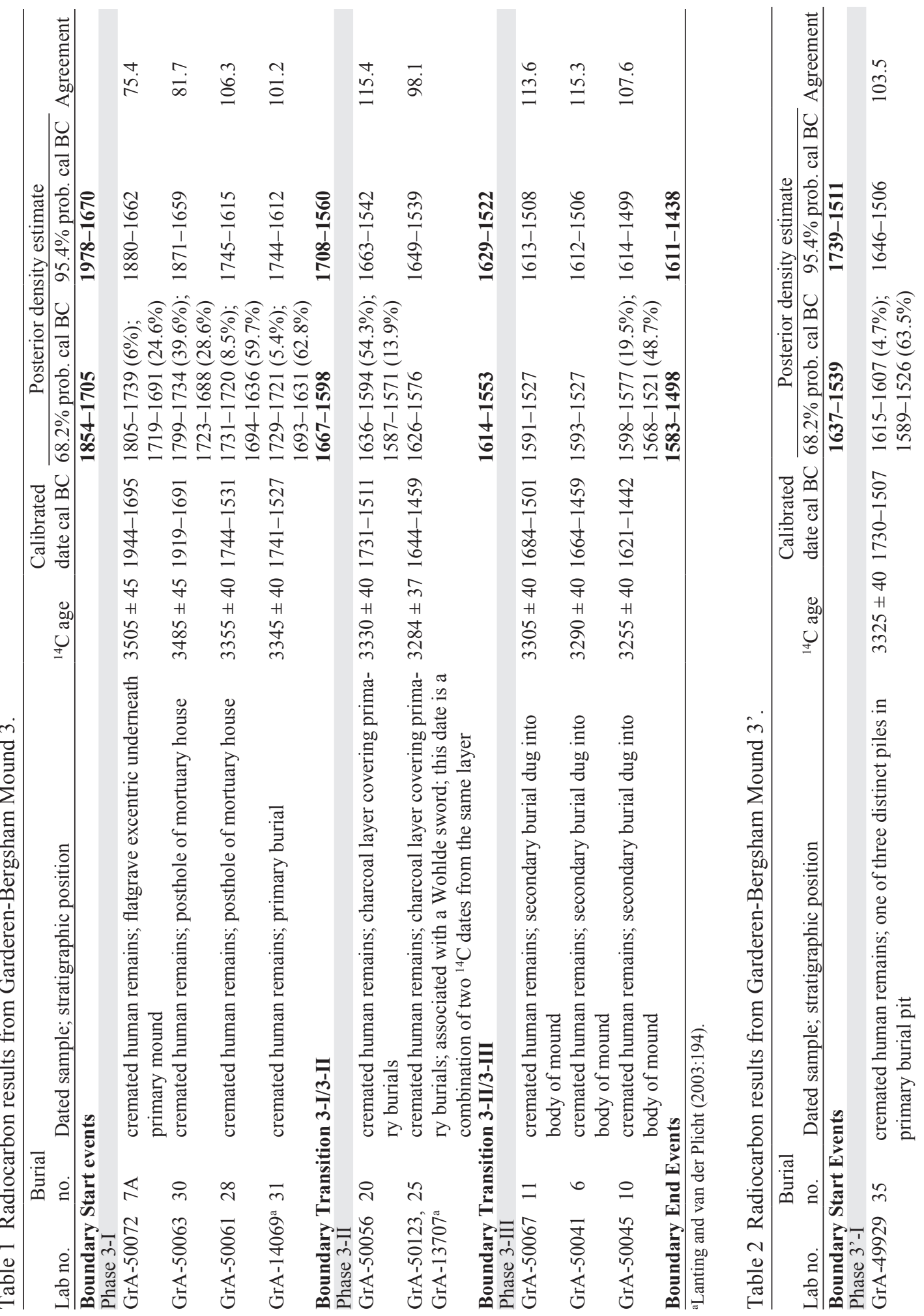


Tempo of Bronze Age Barrow Use
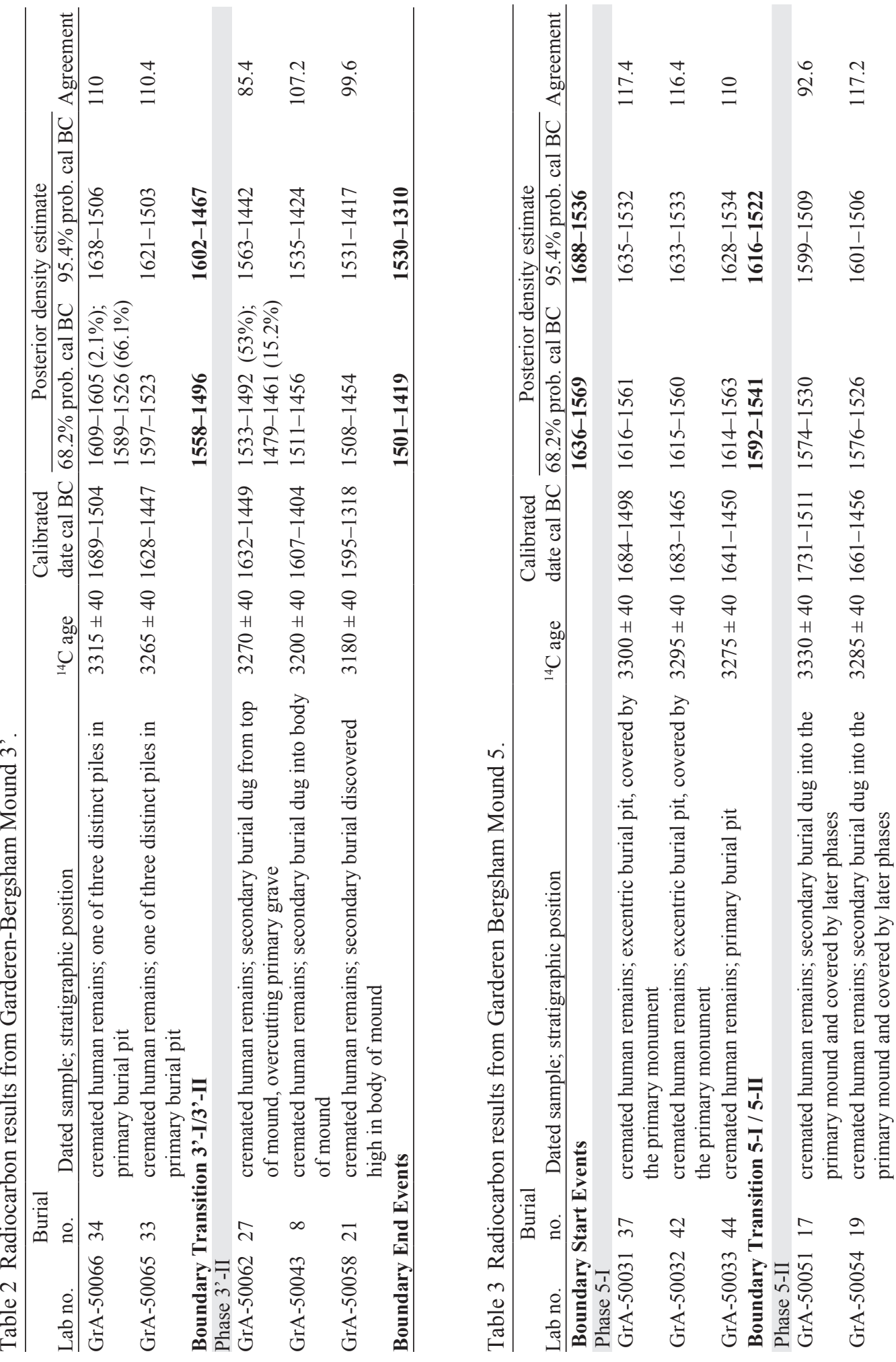


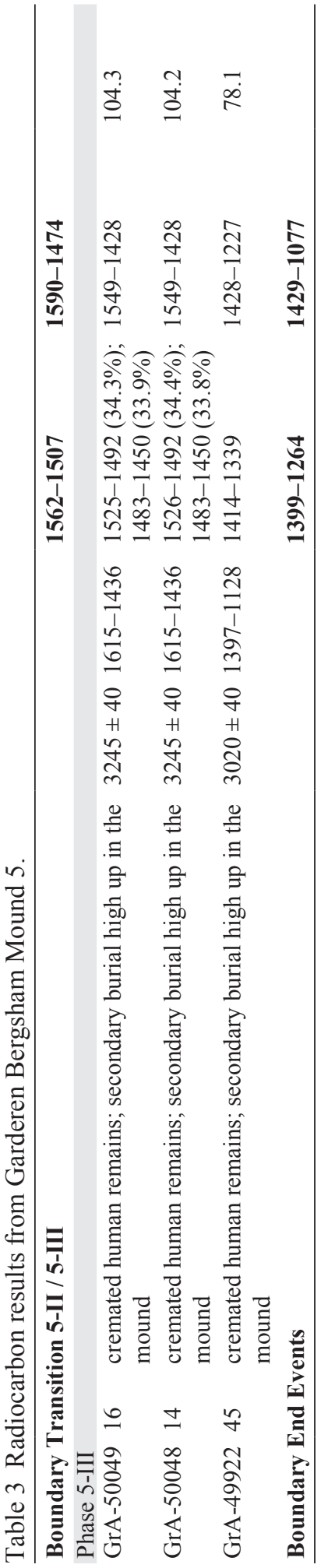
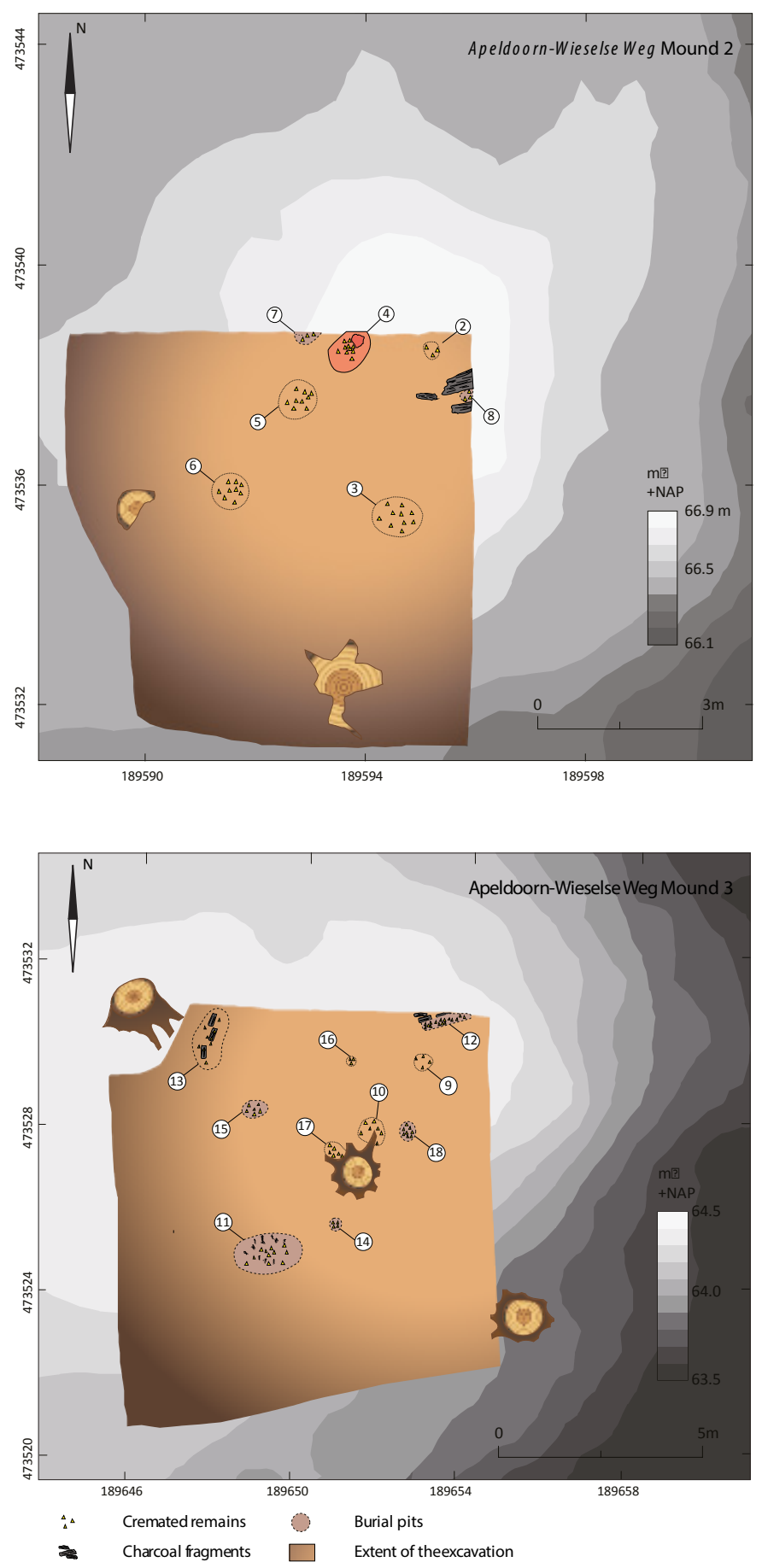

Figure 7 Composition of multiple excavation plans from several levels within mound 2 and mound 3 at Apeldoorn-Wieselse Weg. Copyright Leiden University. 
Both mounds, located some $20 \mathrm{~m}$ from one another, are relatively low and were heavily damaged by ploughing and bioturbation. Nevertheless, we could establish that both barrows covered the cremated remains of both adults and children. Underneath and within the mounds, the remains of at least 18 individuals were discovered, in most cases of women and children (Smits 2011b).

Due to the damage to both monuments, it was not always easy to see which burials can be considered pre-barrow and which can be considered secondary. For barrow 2, we are certain that the mound covered burials 6 and 8 , and that burials 2,4 , and 7 were dug into the body of the mound (Louwen et al. 2014). We have reason to believe that grave 3 and 5 also predate the construction of the mound, but here we are not entirely certain (see Louwen et al. 2014). For what follows, we assumed that 3 and 5, like 6 and 8 , predate the mound.

Unfortunately, for barrow 3, the stratigraphy is less clear, due to the low height of the covering mound, extensive plough damage, as well as bioturbation and soil-formation processes. We can only reliably state that the barrow was constructed on top of burial 12, while burials 9 and 10 were dug into it. For the other burials $(11,13,14,15,16,17$, and 18), we have to resort to more circumstantial arguments to infer their stratigraphic position. This means that the mound 3 graves will be only used to inform us on the duration of barrow use and on the chronological relation between the adjacent mounds 2 and 3 (were these used at the same time, or was one the successor of the other?).

The following section will present two models for mound 3: a minimal model and a maximal one. In the minimal model, only the burials for which we have reliable stratigraphic information have been included (burials 12, 9, and 10). In the maximal model, we assumed that burials 11 and 13 are like 12 covered by the barrow. The depth at which they were found, as well as the fact that we are dealing with large pits containing scattered cremated bone and pyre debris, are arguments for this. However, there are also doubts (Louwen et al. 2014). In the maximal model, we assumed that burials 9, 10, 14, $15,16,17$, and 18 represent a secondary burial phase, as these are all small clumps of cremated bone that could be easily dug into an existing mound. However, we have doubts about this interpretation as well, as some were found in deep positions (Louwen et al. 2014).

\section{Wieselse Weg Models}

The stratigraphic position of each burial was used to construct a chronological model for both barrow 2 and 3 (Figures 8, 9 and 10; Tables 4, 5, and 6). The model for barrow 2 and the maximal model for barrow 3 have good overall agreement ( $\mathrm{A}_{\text {overall }}=88.9 \%$ and $80.3 \%$, respectively), while the minimal model for barrow 3 has a lower agreement $\left(\mathrm{A}_{\text {overall }}=62 \%\right)$. The latter can be attributed to the low number of burials included in the model and the fact that the ${ }^{14} \mathrm{C}$ date of burial 9 is considerably later than both burials 10 and 12 (both calibrated and modeled). Along with the construction of the chronological model, the timespan of each phase and the interval in between has been calculated as well (Figure 11).

The minimal model for mound 3 suggests it was the first monument to be constructed at the entire site. It covered the primary burial (12) and was probably constructed between 1730 and $1545 \mathrm{cal}$ BC (at $95.4 \%$ probability). Within two or three generations (within 1-77 yr at 95.4\%), both secondary burials ( 9 and 10) were inserted into the mound. They are estimated to have been added to the mound between 1660 and $1530 \mathrm{cal} \mathrm{BC}$ for burial 10 and 1630 and 1460 for burial 9 (at $95.4 \%$ ). The calculated timespan in between burials 9 and 10 is estimated to be between 1-138 yr (at 95.4\%).

The maximal, more tentative, model illustrates the same trend as the minimal model. However, it restricts the point in time when the first burials were placed here, somewhere between 1690 and 

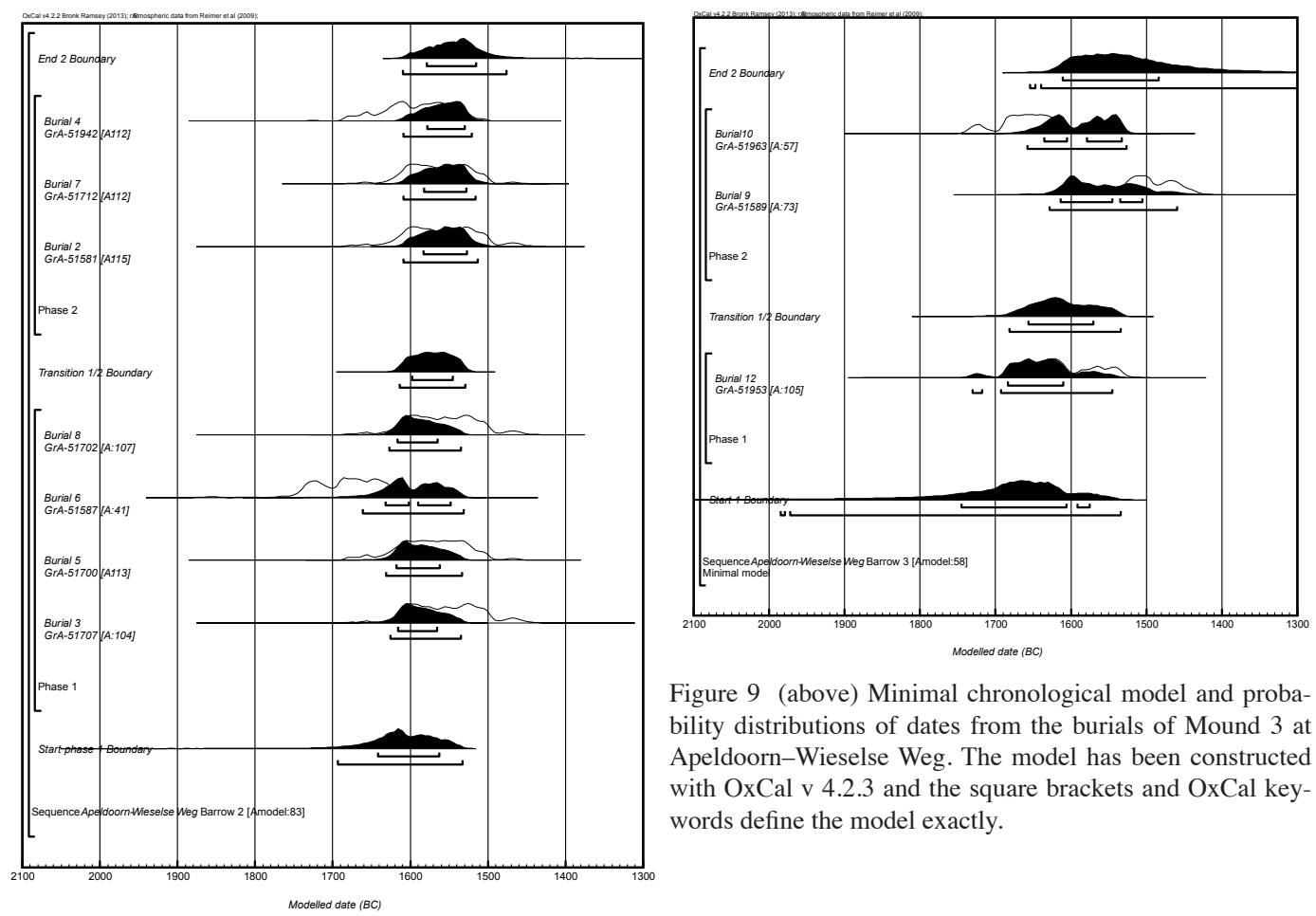

Figure 9 (above) Minimal chronological model and probability distributions of dates from the burials of Mound 3 at Apeldoorn-Wieselse Weg. The model has been constructed with OxCal v 4.2.3 and the square brackets and OxCal keywords define the model exactly.

Figure 8 (above left) Probability distributions of dates from the burials of Mound 2 at Apeldoorn-Wieselse Weg. The model has been constructed with OxCal v 4.2.3 and the square brackets on the left and OxCal keywords define the model exactly.

$1625 \mathrm{cal} \mathrm{BC}$ (at $95.4 \%$ probability). It furthermore suggests that the secondary burials were added to mound 3 quickly after its construction. If we inspect the individual posterior density estimates, the majority of the secondary burials were added to mound 3 between $1665-1600$ cal BC (at $95.4 \%$ probability; burials $10,14-18)$. The poor agreement $(\mathrm{A}=21.4 \%)$ of burial 9 with the maximal model probably suggests that it is considerably later than this series of burials, and likely dates to the 16th century cal BC.

The chronological model for barrow 2 suggests that the majority of the events here took place after most of the people were buried underneath and within mound 3. The individual posterior density estimates calculated for the primary burials suggest they were all placed here between roughly $1625-1535$ cal BC. Interestingly, grave 6 has poor agreement with the overall model (A $=40.7 \%)$, suggesting that it is probably much older than the other primary burials. Furthermore, its calibrated age range (at $2 \sigma$ ) indicates that it may have been contemporary to the events taking place at mound 3 . This indicates that the area underneath what was to become mound 2 was probably already in use for flat grave burial long before the construction of a monument (at least 2 or 3 generations). The longer use of the area as a burial location is reflected in the estimated timespan in between the burials. The model suggests the deaths of the individuals in the secondary burials occurred within 1-84 $\mathrm{yr}$ $(95.4 \%)$.

As with barrow 3 , the first of the secondary burials was added to barrow 2 shortly after the last of the primary burials. The estimated interval of time (Figure 11) between these two phases is only 1-30 yr (95.4\%), but possibly only $1-10 \mathrm{yr}(68.2 \%)$ ! Most of the secondary burials were probably added 
to the monument in the period between $1610-1515 \mathrm{cal} \mathrm{BC}(95.4 \%)$. The estimated timespan in between the burials suggests the deaths of all individuals occurred within half a century of one another.

Summarizing, the events and phases at the Wieselse Weg barrows seem to have taken place in quick succession of one another. According to both the minimal and maximal model, at least one individual was interred underneath barrow 3, possibly in the first half of the 17th century, with the secondary burials added very shortly afterwards, possibly in the second half of the 17 th century BC. Mound 2 was then constructed in the late 17th century BC or the early 16th century BC on a location where there already were flat graves. The secondary burials in mound 2 were then added to the site in the remainder of the 16th century BC. The chronological model developed for this site illustrates how first one monument was constructed and used for secondary burials before people built a new monument. And at the same time it illustrates how the monumentalization of the site must be seen as a particular phase within a more complex use of the site.

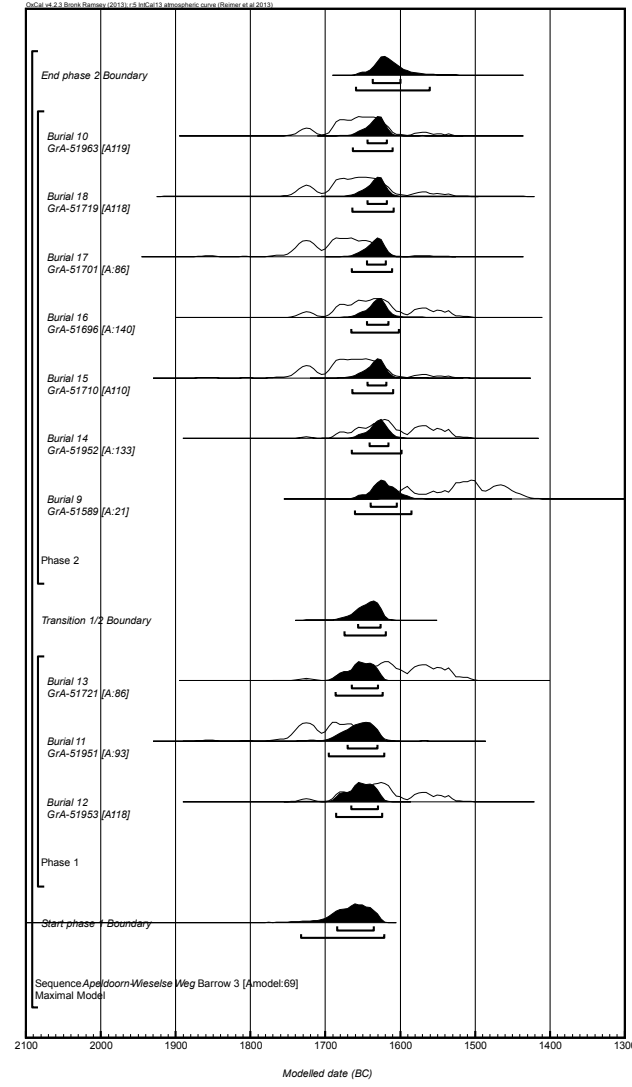

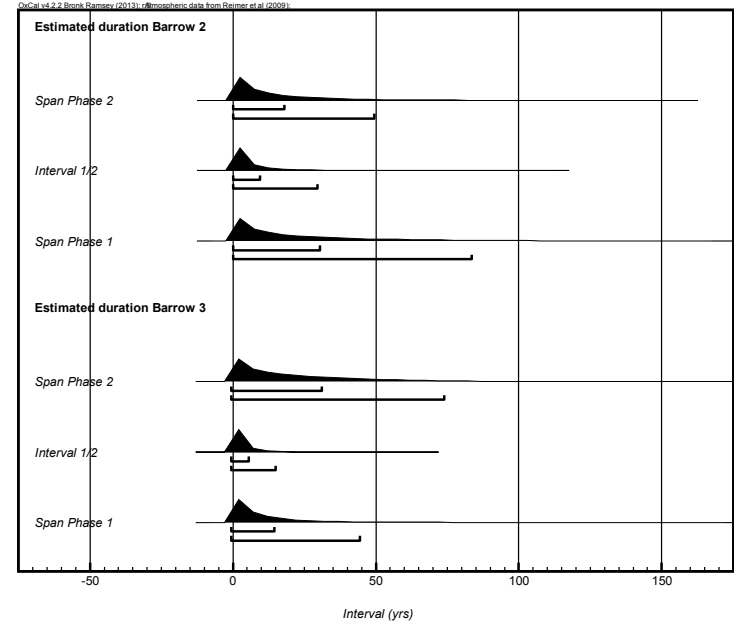

Figure 11 (above) Probability distributions estimating the duration and interval between each phase at the Apeldoorn-Wieselse Weg site. These distributions are derived from the models in Figures 7 and 9.

Figure 10 (left) Maximal chronological model and probability distributions of dates from the burials of Mound 3 at ApeldoornWieselse Weg. The model has been constructed with OxCal v 4.2.3 and the square brackets and OxCal keywords define the model exactly.

\section{DISCUSSION}

The chronological models underline the long-term and episodic nature of such a monumental landscape. On the one hand, there is evidence for protracted histories and on the other for short punctuated events.

At Bergsham, the site was already in use as a burial place sporadically for at least a century or two before the monumental phase of the site. We have also seen that at the location of every mound, peo- 


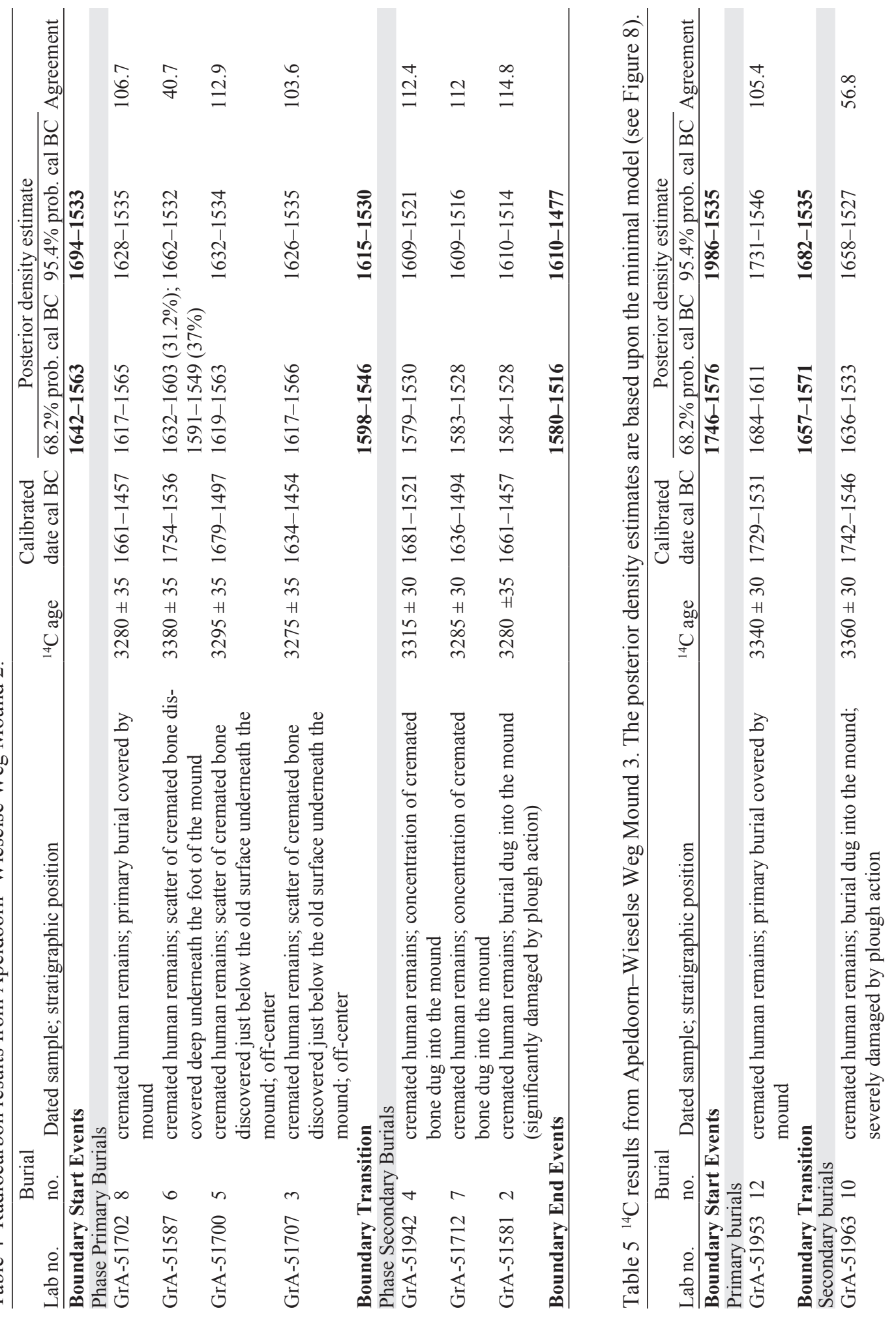


Tempo of Bronze Age Barrow Use

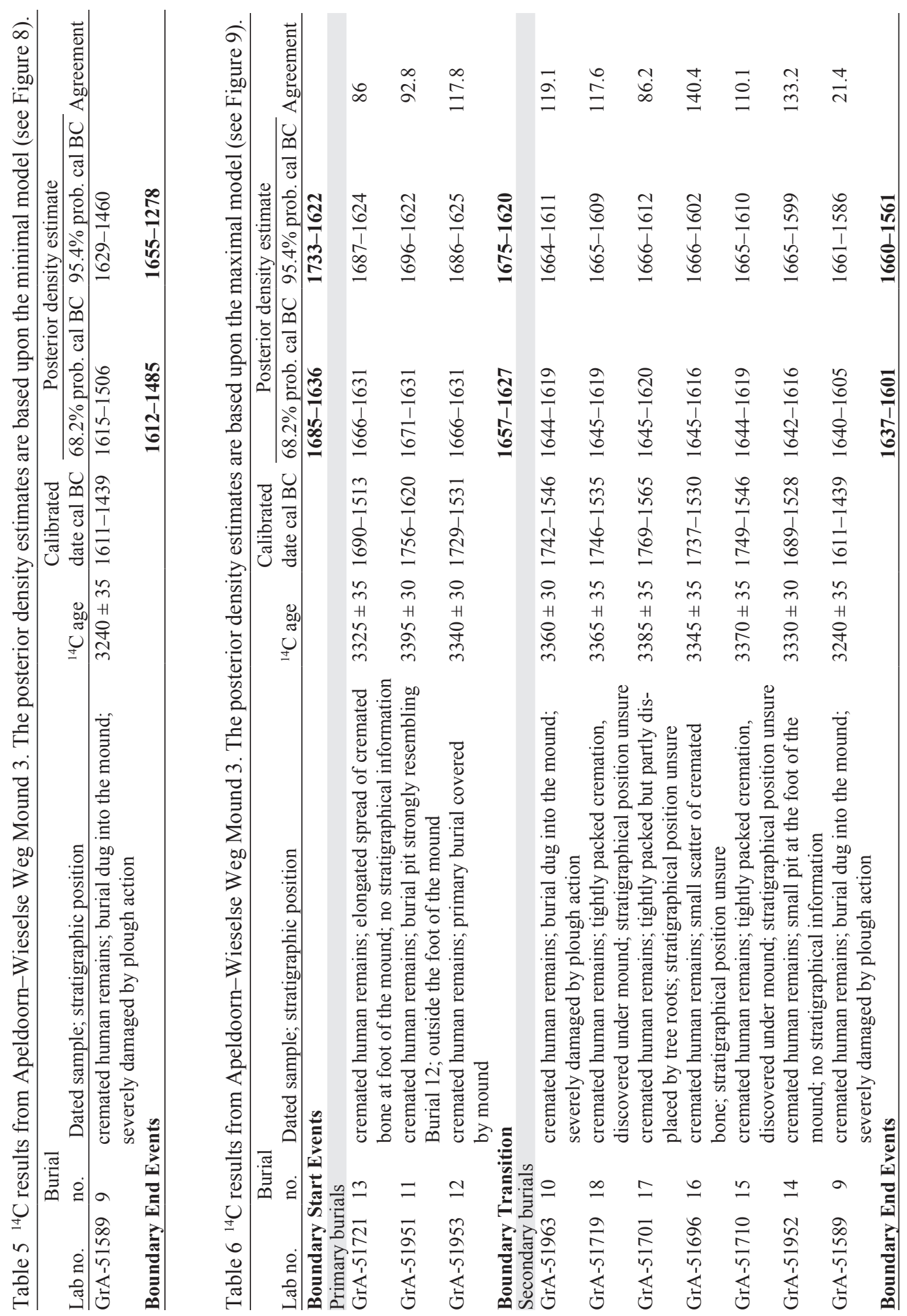


ple were already buried before a true mound was built. Once the mounds were in place, the models suggest that the significant extension of mound 3 and the construction of mounds 3 ' and 5 probably can be restricted to just $50 \mathrm{yr}$ of one another. Then, the majority of the secondary burials were added to the mounds within roughly $100 \mathrm{yr}$, although a few were added long after that. This implies that once the monumental outline of the area was in place, the monuments themselves were used for funerals within a brief period of time as recipient for the remains of the dead.

At the Wieselse Weg site, each mound and its accompanying burials succeed one another. First, mound 3 was constructed over at least one grave and quickly afterwards people were buried within that monument. The estimated durations suggest all this occurred within a couple of decades. After these events had finished, they constructed a new monument close by (mound 2). This mound was built at a location where there was a flat grave present, probably even preceding the monument's construction by several decades. And once again, within a few years, secondary burials were added to mound 2 and a single one to mound 3 . So, in contrast to Bergsham, here we have a situation where the barrows can be seen as each other's successors.

The implications of these chronological models are manifold:

- First, the short activity phases as evidenced at Bergsham indicate that the majority of the people buried during those phases must have known one another and considered themselves as part of the same social whole (however defined). This fuels suggestions that have been done by other scholars a long time ago that could never be truly supported by evidence at that time (e.g. Lohof 1994:102). The models for the Wieselse Weg indicate a similar process: There is only a very brief period of time in between the primary burials and secondary burials at the Wieselse Weg barrows, possibly even within 8 to $10 \mathrm{yr}$ (at $68.2 \%$ probability).

- Secondly, the models also suggest there are long periods of inactivity between some of the events. At Bergsham, the construction of the mortuary house probably predates the extension and construction of mounds $3,3^{\prime}$, and 5 by several decades. This means we must deal with long periods of time in which no deceased were buried here - periods where we have no evidence for activities. We do not know what happened in those periods, but it seems that people moved on and shifted their attention to another location only to return after a while. Perhaps it is precisely such a shift that we see at the Wieselse Weg excavation where they first built mound 3 and then moved towards mound 2 after probably some $50 \mathrm{yr}$ had passed. At Bergsham, both barrows 2 and 4 have not been (entirely) excavated and/or not dated, and it may well be that the apparent "gaps" in the sequence can be found there.

- Thirdly, monumentalization can be restricted to a particular stage in the use of the area as a burial place. In some cases, the area was already in use for a considerable long period of time prior to the construction of the mound (particularly barrow 3-I at Bergsham and barrow 2 at the Wieselse Weg), perhaps even for more than a century. And once constructed, the mounds themselves then remained a focal point for burial for several decades afterwards.

- And lastly, at both Bergsham and Wieselse Weg clear choices were made in where one was to be buried. At the Wieselse Weg site, the secondary burials were added to a specific barrow at a specific point in time (first mound 3, then mound 2). At Bergsham, selection is expressed through the presence of inhumation burials. These are present in both mound 3' and mound 5, but not in mound 3. Also, the physically joining of mound 3 and mound 3' under one single barrow at some point in time may represent a deliberate choice by the prehistoric mourners. Such selections must have had a social meaning, perhaps governed along specific lines of kinship (Bourgeois 2013:174-6). 
Tempo of Bronze Age Barrow Use

\section{CONCLUSION}

The use of Bayesian statistics and the creation of chronological models have allowed us to investigate the development of these funerary landscapes in much greater detail than the general chronologies or unmodeled ${ }^{14} \mathrm{C}$ dates would have allowed us to do. The next step would be to do the same for ${ }^{14} \mathrm{C}$-dated graves from other Bronze Age barrows. Do they reveal patterns of use similar to the models presented here, or not?

The implications of refined chronological models go beyond the creation of shorter histories. Discussing the implications in detail would take us well beyond the scope of this article. Suffice it to say that models like the ones presented here potentially go back to social preferences (based on inheritance? kinship?) for burying the dead in specific places and monuments within barrow landscapes. Thus, detailed insight into chronology may help us to reconstruct the social landscape within which these people operated.

\section{ACKNOWLEDGMENTS}

${ }^{14} \mathrm{C}$ dating the Bergsham data was made possible by a grant of the Province of Gelderland, the $\mathrm{Mu}$ nicipality of Barneveld and Museum Nairac. Thanks are due to P Schut (regional archaeologist), M de Rooij (province of Gelderland), E van de Velde (Museum Nairac), and K Wentink (Leiden University). The Municipality of Apeldoorn, the Royal Estate Kroondomein 't Loo, and the Faculty of Archaeology of the University of Leiden provided financial and logistic aid with the research at Apeldoorn-Wieselse Weg. The Groningen Institute of Archaeology is thanked for their permission to use Figure 2. For the Wieselse Weg project, many thanks are due to M Wispelwey, M Parlevliet (both municipality of Apeldoorn), Dr J Kuper (Royal Estate), and A Louwen, and C van der Linde (both Leiden University). The Dutch Organisation for Scientific Research [project "Ancestral Mounds" (second author) and a Rubicon grant entitled "Along Ancestral Lines," project no. 44612-014, awarded to the first author] made the writing of this article and the ${ }^{14} \mathrm{C}$ research of the latter site financially possible. We are greatly indebted to all.

\section{REFERENCES}

Bailey G. 2007. Time perspectives, palimpsests and the archaeology of time. Journal of Anthropological Arcchaeology 26(2):198-223.

Bayliss A. 2009. Rolling out revolution: using radiocarbon dating in archaeology. Radiocarbon 51(1):12347.

Bayliss A, van der Plicht H, Bronk Ramsey C, McCormac G, Healy F, Whittle A. 2011. Towards generational time-scales: the quantitative interpretation of archaeological chronologies. In: Whittle A, Healy F, Bayliss A, editors. Gathering Time: Dating the Early Neolithic Enclosures of Southern Britain and Ireland. Oxford: Oxbow Books. p 17-59.

Bourgeois Q. 2013. Monuments on the Horizon. The Formation of the Barrow Landscape throughout the 3rd and 2nd Millennium BCE. Leiden: Sidestone Press.

Bradley R. 2003. The translation of time. In: Van Dyke RM, Alcock SE, editors. Archaeologies of Memory. Oxford: Blackwell. p 221-7.

Bronk Ramsey C. 2009. Bayesian analysis of radiocarbon dates. Radiocarbon 51(1):337-60.

Garwood P. 2007. Before the hills in order stood: chronology, time and history in the interpretation of Early Bronze Age round barrows. In: Last J, editor. Beyond the Grave, New Perspectives on Barrows. Oxford: Oxbow Books. p 30-52.

Glasbergen W. 1954. Barrow excavations in the Eight Beatitudes. The Bronze Age cemetery between Toterfout \& Halve Mijl, North Brabant. I. The excavations. Palaeohistoria 2:1-134.

Gosden C, Lock G. 1998. Prehistoric histories. World Archaeology 30(1):2-12.

Holst MK. 2013. Time and space. In: Holst MK, Rasmussen M, editors. Skelh $\phi j$ and the Bronze Age Barrows of Southern Scandinavia. Volume I: The Bronze Age Barrow Tradition and the Excavation of Skel$h \phi j$. Højbjerg: Jutland Archaeological Society.

Lanting JN, van der Plicht H. 2003. De ${ }^{14} \mathrm{C}$ chronologie van de Nederlandse Pre- en Protohistorie IV: Bronstijd en Vroege Ijzertijd. Palaeohistoria 43-44:117261.

Lohof E. 1994. Tradition and change. Burial practices in the Late Neolithic and Bronze Age in the north-eastern Netherlands. Archaeological Dialogues 1(2):98-119. 
Louwen A, Fontijn DR, Bourgeois QPJ. 2014. Stratigraphy of the graves in burial mound 2 and 3 of Apeldoorn-Wieselse Weg - preliminary data report. https://leidenuniv.academia.edu/DavidFontijn.

Mizoguchi K. 1993. Time in the reproduction of mortuary practices. World Archaeology 25(2):223-35.

Reimer PJ, Bard E, Bayliss A, Beck JW, Blackwell PG, Bronk Ramsey C, Buck CE, Cheng H, Edwards RL, Friedrich M, Grootes PM, Guilderson TP, Haflidason H, Hajdas I, Hatté C, Heaton TJ, Hoffman DL, Hogg AG, Hughen KA, Kaiser KF, Kromer B, Manning SW, Niu M, Reimer RW, Richards DA, Scott EM, Southon JR, Staff RA, Turney CSM, van der Plicht J. 2013. IntCal13 and Marine13 radiocarbon age calibration curves $0-50,000$ years cal BP. Radiocarbon 55(4):1869-87.

Smits L. 2011a. Rapportage Crematieonderzoe Bergsham-Garderen (internal report). Leiden: Leiden University.

Smits L. 2011b. Analyse van de crematiegraven van de grafheuvels te Apeldoorn-Wieselse Weg (internal report). Leiden: Leiden University.

Van Giffen AE. 1937. Tumuli-opgravingen in Gelderland, 1935/1936. Gelre 40:3-18.

Van Strydonck M, Boudin M, De Mulder G. 2009. ${ }^{14} \mathrm{C}$ dating of cremated bones: the issue of sample contamination. Radiocarbon 52(2):578-86.

Whittle A. 2011. Grand narratives and shorter stories. In: Hadjikoumis A, Robinson E, Viner S, editors. The Dynamics of Neolithisation in Europe: Studies in Honours of Andrew Sherratt. Oxford: Oxbow Books. p 10-24.

Whittle A, Bayliss A. 2007. The times of their lives: from chronological precision to kinds of history and change. Cambridge Archaeological Journal 17(Supplement 1):21-8.

Woodward AB, Woodward PJ. 1996. The topography of some barrow cemeteries in Bronze Age Wessex. Proceedings of the Prehistoric Society 62:275-91. 